\title{
PERTANGGUNGJAWABAN BANK TERHADAP HAK NASABAH YANG DIRUGIKAN DALAM PEMBOBOLAN REKENING NASABAH (STUDI DI PT. BANK RAKYAT INDONESIA TBK, KANTOR CABANG MEDAN GATOT SUBROTO)
}

\author{
Andi Nova Bukit \\ Fakultas Hukum, Universitas Tjut Nyak Dhien \\ E-mail : andy_bukit@yahoo.com
}

\begin{abstract}
Abstrak
Bank, baik bank sentral maupun bank umum merupakan inti dari sistem keuangan setiap negara. Bank merupakan lembaga keuangan yang menjadi tempat bagi perusahaan, badan-badan pemerintah dan swasta maupun perorangan menyimpan dana-dananya. Melalui kegiatan perkreditan dan berbagai jasa yang diberikan, bank melayani kebutuhan pembiayaan dan mekanisme sistem pembayaran bagi semua sektor perekonomian. Metode penelitian yang digunakan yaitu yuridis empiris. Penelitian ini membahas tentang bagaimana pertanggung jawaban bank terhadap nasabah yang dirugikan.Bank berfungsi sebagai perantara pihak-pihak yang mempunyai kelebihan dana dengan pihak-pihak yang kekurangan dan memerlukan dana, serta melayani kebutuhan pembiayaan serta melancarkan mekanisme sistem pembayaran bagi semua sektor perekonomian masyarakat. Kondisi yang demikian, maka bank adalah lembaga yang mengandalkan kepercayaan masyarakat terhadap bank, pemerintah harus berusaha melindungi masyarakat sebagai nasabah dari tindakan lembaga ataupun oknum pegawai bank yang tidak bertanggung jawab dan merusak sendi kepercayaan masyarakat.

Kata Kunci: Pertanggungjawaban; Hak Nasabah; Perlindungan Hukum
\end{abstract}




\title{
BANK'S LIABILITY FOR CUSTOMER'S RIGHTS WICH DURED IN BREAKING THE CUSTOMER ACCOUNT (STUDY AT PT. BANK RAKYAT INDONESI TBK, MEDAN GATOT SUBROTO BRANCH OFFICE)
}

\begin{abstract}
Banks, both central banks and commercial banks are the core of each country's financial system. The bank is a financial instution which is a place for companies, government agencies and private and individual to store funds. Though lending activities and various services provided, banks serve financing needs amd payment system mechanisms for all sectors of the economy. This journal discusses how the bank is liable to the injured customer. Where the bank functions as an intermediary between parties who have excess funds with those who lack and need funds, as well as serving financing needs and expediting payment system mechanisms for all sectors of the community's economy. Such conditions, the bank is an institution that relies on public trust in banks, the government must try to protect the community as a customer from the actions of institutions or unscrupulous bank employees who damage the joints of public trust.

Keywords: accountability; customer rights; legal protection
\end{abstract}




\section{PENDAHULUAN}

\section{Latar Belakang}

Perkembangan zaman dan teknologi di dunia ini, tidak diragukan lagi telah membawa dampak yang sangat berarti terhadap perkembangan seluruh negara. Tidak terkecuali Indonesia. Perkembangan yang terjadi tersebut mencakup di segala bidang kehidupan, termasuk bidang perekonomian. Semakin banyaknya kegiatan ekonomi yang dilakukan, tentu saja akan berbanding lurus dengan semakin cepatnya perputaran uang yang terjadi di dalamnya.

Perbankan adalah badan usaha yang menghimpun dana dari masyarakat dalam bentuk simpanan dan menyalurkannya kepada masyarakat dalam bentuk kredit atau bentuk-bentuk lainnya dalam rangka meningkatkan taraf hidup rakyat banyak. Bank memiliki tanggung jawab yang besar terhadap pembangunan ekonomi. Tanggung jawab tersebut berasal dari tugas dan fungsinya sebagai perantara antara dana yang disimpan oleh masyarakat kemudian disalurkan. Kembali dalam bentuk kredit tersebut yang nantinya akan dapat digunakan sebagai alternatif yang dapat meningkatkan pembangunan ekonomi sehingga benar bahwa Bank merupakan faktor yang dapat meningkatkan pertumbuhan ekonomi. ${ }^{1}$

1 Margareta Waworuntu, Tri Oldy Rotinsulu, Dennij Mandeij, PeranSektor Perbankan Dalam MengembangkanDaya Saing Usaha Mikro Kecil Dan Menengah (UMKM) Indonesia Memasuki Pasar MEA 2010-2015, Jurnal Berkala Ilmiah Efisiensi
Terhadap kerugian yang dialami nasabah, Bank Indonesia telah menghimbau bank untuk tetap memperhatikan prinsip perlindungan nasabah. Dalam hal ini, apabila nasabah merasa terdapat transaksi yang mencurigakan pada rekeningnya, dapat segera menghubungi bank di mana nasabah membuka rekening. Bank akan melakukan investigasi terhadap laporan yang masuk berdasarkan bukti-bukti yang ada sesuai dengan aturan/prosedur yang ada. ${ }^{2}$

$$
\text { Lembaga keuangan }
$$

tersebut adalah bank. Pendirian bank di Indonesia bertujuan untuk menunjang pelaksanaan pembangunan nasional dalam rangka meningkatkan pemerataan, pertumbuhan ekonomi, dan stabilitas nasional ke arah peningkatan rakyat banyak. Bank membutuhkan dana yang tidak sedikit. Dana yang dibutuhkan bank tersebut dapat dihasilkan dari dana bank itu sendiri (dana intern) dan dana dari pihak ketiga (dana ekstern). Sumber dana yang berasal dari bank itu sendiri dapat berupa setoran modal/penjualan saham, pemupukan cadangan, laba yang ditahan, dan lain-lain. Dana ini bersifat tetap. Sedangkan dana yang berasal dari dari luar bank seperti rekening giro dan rekening koran, deposito

Volume 17 No 01, 2017, Manado, Fakultas Ekonomi dan Bisnis Universitas Sam Ratulangi, hlm 184.

2 Reza Aditya Pamuji, Perlindungan Hukum Bagi Nasabah dan Tanggung Jawab Bank Dalam Kasus Card Skimming, Jurnal Lex Rennassance Vol 3 No 1, 2018, Yogyakarta, Universitas Islam Indonesia, hlm 37-38. 
berjangka, sertifikat deposito, pinjaman dari lembaga keuangan bank lainnya dan lembaga keuangan bukan bank, penjualan surat berharga (efek-efek) dan sumber lainnya. Semakin lama bank menunjukkan eksistensinya di bidang perekonomian, semakin nyata pula peranan yang dapat bank berikan kepada masyarakat.

Bank menghimpun dana masyarakat (nasabah) dalam bentuk simpanan. Nasabah mempercayai bank sebagai tempat yang aman untuk menyimpan dana (uang) dan melakukan investasi. Keamanan atas dana (uang) yang disimpannya di bank oleh nasabah merupakan faktor yang sangat penting bagi nasabah. Selain rasa aman sebagai tempat untuk menyimpan dan (uang). Nasabah akan merasa lebih aman apabila uangnya diinvestasikan di bank. Return merupakan imbalan yang diperoleh nasabah atas sejumlah dana yang disimpan dibank. Imbalan yang diberikan oleh bank bisa dalam bentuk bunga simpanan untuk bank konvesional atau bagi hasil yang diberikan oleh bank syariah. Sebagai upaya menghimpun dana pihak ketiga, bank menawarkan produk simpanan antara lain dalam bentuk simpanan giro, tabungan, deposito, dan simpanan lainnya yang diperkenankan.

Faktor utama yang menjadi kelemahan konsumen adalah tingkat kesadaran masryakat akan haknya masih rendah. Sebagai usaha melindungi konsumen secara umum sekarang ini telah ada undang-undang yang mengatur, yaitu Undang-Undang
Nomor 8 Tahun 1999 tentang Perlindungan Konsumen. UndangUndang tersebut dimaksudkan untuk menjadi landasan hukum yang kuat, baik untuk pemerintah maupun masyrakat itu sendrir secara swadaya untuk melakukan upaya pemberdayaan konsumen.

Undang-Undang tentang Perlindungan Konsumen ini dirumuskan dengan mengacu filosofi pembangunan nasional bahwa pembangunan nasional termasuk pembangunan hukum yang memberikan perlindungan terhadap konsumen adalah dalam rangka membangun manusia Indonesia seutuhnya yang berlandaskan pada falsafah kenegaraan Republik Indonesia, yaitu dasar negara Pancasila dan konstitusi negara Undang-Undang Dasar 1945.

Kemajuan teknologi salah satu pelayanan bank adalah dengan diluncurkannya kartu ATM (Automated teller Machine) sebagai salah satu fasilitas yang disediakan oleh bank. Secara harfiah ATM dapat diartikan mesin kasir otomatis, dalam bahasa Indonesia sehari-hari dikenal istilah Anjungan Tunai Mandiri yang berarti alat kasir otomatis tanpa orang, ditempatkan didalam atau diluar pekarangan bank yang sanggup mengeluarkan uang tunai dan menangani transaksi-transaksi perbankan secara rutin, seperti penyetoran, penarikan uang, transfer antar rekening, pelunasan atau pembayaran tagihan kartu kredit. Perlindungan hukum ini sangat diperlukan, karena walaupun bank telah memberikan jaminan 
keamanan berlapis untuk
keamanan bertransaksi secara
elektronik ini, namun tetap saja
ada nasabah yang dirugikan
karena menggunakan pelayanan
ini.

Hubungan hukum antara nasabah dengan bank didsarkan atas adanya suatu perjanjian di antara mereka. Sebagaimana diatur dalam Pasal 1339 jo Pasal 1347 KUHPerdata, suatu perjanjian tidak hanya mengikat untuk hal-hal yang dengan tegas dinyatakan di dalamnya, tetapi juga untuk segala sesuatu yang menurut sifat perjanjian, diharuskan oleh kepatutan, kebiasaan atau undangundang. Jadi dalam hubungan hukum antara nasabah dengan bank, para pihak berkewajiban melaksanakan hak dan kewajibannya masingmasing, baik mengenai hal-hal yang dengan tegas disebutkan dalam perjanjian yang dibuat secara tertulis, maupun menurut kebiasaan yang berlaku dan diterima secara umum. ${ }^{3}$

Pengaduan nasabah adalah bentuk perwujudan dari perlindungan hak yang dimiliki oleh nasabah yaitu hak untuk di dengar. Hak tersebut diatur di dalam Pasal 4 huruf d UndangUndang 8 Tahun 1999 tentang Perlindungan Konsumen (UU PK). Sedangkan pada sektor jasa keuangan, terdapat Pasal 32 Peraturan Otoritas Jasa Keuangan

3 Wafiya, Perlindungan Hukum Bagi Nasabah Yang Mengalami Kerugian Dalam Transaksi Perbankan Melalui Internetg, Jurnal Ilmu Hukum Kanun No 56 Th. XIV, 2012, Banda Aceh, Fakultas Hukuk Universitas Syiah Kuala, hlm 43.
Nomor 1/POJK.07/2013 tentang Perlindungan Konsumen Sektor Jasa Keuangan (POJK PK) yang mengatur bahwa pelaku usaha sektor jasa keuangan wajib memiliki dan melaksanakan pelayanan dan penyelesaian pengaduan nasabah. . ${ }^{4}$

Perlindungan hukum

nasabah pengguna ATM (Automated Teller Machine) dapat berupa perjanjian hak dan kewajiban bank dan nasabah pada saat pembukaan rekening tabungan, bank menyediakan informasi yang lengkap, jelas dan akurat mengenai produk bank serta transparansi penggunaan data pribadi nasabah, sengketa yang terjadi antara nasabah dan bank dapat diselesaikan dengan mediasi perbankan, serta penyusunan mekanisme pengaduan nasabah.

Penyelesaian sengketa antara bank dengan nasabah pengguna ATM (Automated Teller Machine) jika terjadi kehilangan dana tabungan dapatdiselesaikan dengan mediasi perbankan. Prosesnya yaitu diajukan oleh nasabah atau perwakilan nasabah kepada Bank Indonesia, proses mediasi dilakukan setelahnasabah atau perwakilan nasabah dan bank menandatangani perjanjian mediasi, dilakukan dalam jangka waktu 30 hari kerja dan dapat diperpanjang selama 30 hari kerja berikutnya. Hasil kesepakatan

\footnotetext{
4 Satria Perdana Devanto, Perlindungan Nasabah Dalam Transaksi Melalui Internet Banking, Jurnal Privat Law Vol 6 No 1, 2018, Solo, Universitas Negeri Sebelas Maret, hlm 148.
} 
antara nasabah atau perwakilan nasabah dengan bank dituangkan dalam Akta Kesepakatan yang ditandatangai oleh kedua belah pihak, dan bank wajib melaksanakan hasil penyelesaian sengketa.

\section{Rumusan Masalah}

Perumusan masalah merupakan hal yang penting, agar dalam penelitian dapat lebih terarah dan terperinci sesuai dengan tujuan yang dikehendaki. Perumusan masalah dalam penelitian ini adalah sebagai berikut :

1. Bagaimana Pertanggung Jawaban Bank Rakyat Indonesia, Tbk, Kantor Cabang Medan Gatot Subroto terhadap Nasabah yang dirugikan?

2. Bagaimana Hak dan Kewajiban Nasabah serta perlindungan hukumnya?

\section{Metode Penelitian}

Penelitian adalah usaha atau pekerjaan untuk mencari kembali yang dilakukan dengan suatu metode tertentu dengan cara hati-hati, sistematis serta sempurna terhadap permasalahan, sehingga dapat digunakan untuk menyelesaikan atau menjawab problemnya. Spesifikasi penelitian ini juga bersifat analitis deskriptif yaitu merupakan metode penelitian yang berusaha menggambarkan objek atau subjek yang diteliti sesuai dengan apa adanya, dengan tujuan menggambarkan sistematis, fakta dan

\begin{abstract}
karakterisitik objek yang diteleliti secara tepat.

Penelitian ini berusaha untuk menjelaskan dan menggambarkan secara sistematis dan rinci mengenai Pertanggung Jawaban Hukum Oleh Perbankan Terhadap Nasabah Yang Mengalami Kerugian Dalam Pembobolan Rekening Nasabah. Metode pendekatan yang digunakan dalam penelitian ini adalah metode penelitian yuridis empiris. Selain metode pendekatan yuridis empiris penelitian ini juga menggunakan penelitian yuridis normatif.

Penelitian ini diarahkan sebagai penelitian hukum, yaitu penelitian terhadap bahan pustaka dan penelitian lapangan terdiri dari: bahan hukum primer, bahan hukum sekunder dan bahan hukum tersier. Teknik analisis data yang dipakai adalah teknis analisis kualitatif.
\end{abstract}

\section{PEMBAHASAN}

\section{A. Pertanggung Jawaban Bank Terhadap Nasabah Yang di Rugikan}

Tujuan dilakukannya penelitian ini adalah untuk mengetahui bagaimana pertanggung jawaban bank terhadap nasabah bank yang di rugikan dan apa saja yang menjadi hak dan kewajiban nasabah serta perlindungan hukumnya. Perbankan sebagai lembaga intermediasi keuangan (financial intermediary 
institution) memegang peranan penting dalam proses pembangunan nasional. Hal ini membuatnya sarat akan pengaturan baik melalui peraturan perundang-undangan di bidang perbankan sendiri maupun perundang-undangan lain yang terkait. UndangUndang Nomor 8 Tahun 1999 tentang Perlindungan Konsumen (selanjutnya disebut UUPK) juga sangat terkait, khususnya dalam hal perlindungan hukum bagi nasabah bank selaku konsumen atau nasabah.

Pertanggung jawaban Bank terhadap nasabah dapat dikaitkan dengan permasalahan perlindungan hukum dari bank, karena bentuk pertanggung jawaban bank tidak terlepas dari undang- undang yang mengikat. Dalam aarsitektur perbankan Indonesia yang di terbitkan Bank Indonesia Tahun 2004, antara laion mengatur tentang perlindungan terhadap nasabah berdasarkan Undang-Undang Nomor 8 Tahun 1999 tentanh perlindungan konsumen.

Bank menjalankan usaha menghimpun dana dari masyarakat dalam bentuk simpanan dan menyalurkannya kembali pada masyarakat dalam bentuk kredit atau bentuk lainnya guna meningkatkan kesejahteraan masyarakat. Dana yang disimpan oleh masyarakat dalam bentuk simpanan tersebut didasarkan atas kepercayaan, maksudnya masyarakat percaya bahwa dana yang disimpan pada bank tersebut akan digunakan oleh bank sesuai dengan keperluannya. Meskipun demikian masyarakat tidak begitu saja pyang melandasi kegiatan industry peercaya, melainkan harua ada mekanisme lain yang dapat menambah keyakinan masyaraklat tersebut atas jaminan keamanan dananya yang tersimpan pada bank.

Perlindungan dan pertanggung jawaban hukum terhadap pihak pihak yang terkait dalam kegiatan dunia perbankan juga dilakukan secara kongkrit atau diatur melalui norma hukum, sebagai perwujudan lebih lanjut dari prinsip prinsip hukum yang melandasi kegiatan Industri perbankan Nasional. Dengan diadakan peraturan dan norma hukum yang mengikat perbankan di harapkan dapat diketahui secara jelas hakl dan kewajiban pihak pihak yang terkait dalam kegiatan Industri perbankan.

Bank dengan nasabah didasarkan pada hubungan kepercayaan dan hubungan hukum. Hubungan atas dasar kepercayaan maksudnya nasabah menyimpan uangnya pada bank didasarkan atas kepercayaan bahwa bank mampu mengelola sejumlah uang yang disimpan tersebut. Sedangkan hubungan hukum, yaitu hubungan yang menimbulkan akibat hukum yang mengikat antara pihak bank dengan pihak nasabah pengguna jasa bank yang bersangkutan.

Pertanggung jawaban bank yaitu, mengatur dan mengawasi bank yang dilakukan oleh Bank Indonesia termasuk pula dalam 
hal terjadi perubahan atas peralihan kepemilikan bank, khususnya, data nasabah, menyangkut masalah perizinan, di antaranya: Pemberian persetujuan atas kepemilikan dan kepengurusan bank yaitu menyangkut ke-lembagaan bank dalam hal pemilikan dapat berkaitan dengan merger, konsolidasi dan akuisisi.

Bank memiliki izin, ketentuan ketentuan perjanjian kredit dan dalam hal data nasabah, pelayanan bank dan hal yang berkaitan dengan bank terhadap nasabah lainnya mendapat persetujuan dari Bank Indonesia, maka Bank Indonesia sebagai pemegang otoritas seluruh bank, dan bertanggung jawab dengan seluruh bank dan tidak terlepas dari kewajiban kewajiban nasabah bank tersebut.

Pelanggaran hak nasabah oleh bank dapat diselesaikan melalui jalur hukum. Namun ketika kita kembali sadarkan terhadap nilai-nilai Negara hukum Pancasila dan UndangUndang Dasar 1945 yang mengedepankan asas musyawarah, forum mediasi merupakan dimensi yang juga penting. Ketika sengketa perbankan masih dapat diselesaikan secara baik dan tetap menguntungkan kedua belak pihak, maka jalur hukum atau pengadilan dapat dikesampingkan/dihentikan. Hal ini juga terkait dengan prinsip penyelesaian sengketa secara murah, sederhana dan cepat. Hadirnya upaya tersebut tentu tidak terlepas dari hubungan timbal balik antara nasabah dan bank, baik itu nasabah penyimpan dalam bentuk tabungan maupun deposito atau nasabah lain.

Hubungan timbal balik ini dapat berupa pemberian bunga oleh pihak bank terhadap simpanan dari nasabah, serta kewajiban-kewajiban nasabah untuk memenuhi ketentuan sistem administrasi tertentu apabila hendak mengambil atau menyimpan uang. Selain itu sebagai upaya peningkatan dan pemberdayaan nasabah, tentu bank sebagai pelaku usaha harus memberikan layanan penyelesaian dan infrastruktur atas berbagai keluhan dan pengaduan nasabah. Media penyelesaian ini juga harus memenuhi standar waktu dan pelayanan, yang artinya dapat berlaku secara efektif dan efesien.

Bank Indonesia sebagai pemegang otoritas perbankan Indonesia dalam upaya memenuhi standar tersebut juga telah memprioritaskan programprogram terkait perlindungan nasabah, termasuk penanganan pengaduan nasabah, termasuk penanganan perbankanan pembentukan lembaga mediasi perbankan independen. Pada ranah hukum, seorang tentu harus bertanggung jawab terhadap kerugian yang diakibatkan oleh perbuatan yang bertentangan dengan hukum dari orang lain. hal ini disebut tanggung jawab kualitatif, yaitu orang yang bertanggung jawab 
karena orang itu memiliki suatu kwalitas tertentu.

Penerapan hukum di Indonesia, seorang konsumen yang dilakukan oleh pelaku usaha, termasuk nasabah kepada bank, dapat menggugat pihak yang menimbulkan kerugian atas produk dan jasanya tersebut. Kualifikasi gugatan yang lazim adalah wanprestasi atau perbuatan melawan hukum. Dalam gugatan adanya wanprestasi, maka terdapat hubungan kontraktual antara konsumen dan pelaku usaha/produsen. Kerugian yang dialami oleh nasabah tidak lain adalah karena tidak dilaksanakan prestasi oleh bank sebagai pelaku usaha.

Apabila tidak terdapat hubungan kontraktual antara nasabah dan bank, maka tidak ada tanggung jawab (hukum) pelaku usaha nasabah. Hal inilah yang dikenal dengan doktrin yang mengandung prinsip "tidak ada hubungan kontraktual, tidak ada tanggung jawab".

Hubungan kontraktual tidaklah disyaratkan. Dalam hal ini nasabah haruslah membuktikan adanya unsurunsur:

1. Adanya perbuatan melawan hukum,

2. Adanya kesalahan/kelalaian pelaku usaha,

3. Adanya kerugian yang dialami oleh konsumen,

4 . Adanya hubungan kausal antara perbuatan melawan hukum dan kerugian yang dialami oleh konsumen.
Undang-Undang

Perlindungan Konsumen, dalam konteks pertanggungjawaban pelaku usaha atas gugatan nasabah ini, diatur beberapa ketentuan :

1. Pertanggung jawaban Pidana Korporasi Subjek hukum tindak pidana UndangUndang Perlindungan Konsumen adalah pelaku usaha. Pelaku usaha yang termasuk dalam pengertian ini adalah perusahaan, korporasi, BUMN, koperasi, impotir, pedagang, distributor, dan lain-lain. Artinya, bank pemerintah maupun swasta, termasuk Bank Perkreditan termasuk kategori ini.

2. Hak gugat Lembaga Konsumen Lembaga konsumen, atas nama kepentingan konsumen, dapat mengajukan gugatan atas pelanggaran yang dapat dilakukan pelaku usaha yang merugikan kepentingan konsumen (Pasal 46 ayat (1) huruf $c$ UUPK). Disini lembaga konsumen mempunyai hak gugat (legal standing to sue) kepada pelaku usaha, lepas ada atau tidak ada surat kuasa dari konsumen yang dirugikan.

3. Gugatan Kepentingan kelompok Terhadap sengketa konsumen yang melibatkan konsumen dalam jumlah besar/missal, padahal ini persoalaan menyangkut hal yang sama, konsumen dapat mengajukan gugatan kepentingan kelompok ( class 
action ) kepada pelaku usaha (Pasal 46 ayat (1) huruf b UUPK).

4. Beban Pembuktian terbalik Pelaku usaha bertanggung jawab memberikan ganti rugi atas kerusakan, pencemaran, dan/atau kerugian konsumen akibat menggunakan produk atau jasa yang dihasilkan atau diperdagangkan (Pasal 19 ayat (1) UUPK).

Ganti rugi dapat berupa pengembalian uang atau penggantian barang dan/atau jasa yang sejenis atau setara nilainya, atau perawatan kesehatan dan/atau pemberian santunan yang sesuai dengan ketentuan peraturan Perundang-Undangan yang berlaku. Ketentuan ini tidak berlaku apabila pelaku usaha dapat membuktikan bahwa kerugian tersebut merupakan atau sebagai akibat kesalahan konsumen. Sehingga, pembuktian terhadap ada tidaknya unsur kesalahan dalam gugatan- gugatan ganti rugi, merupakan beban dan tanggung jawab pelaku usaha (Pasal 28 UUPK).

Nasabah akan mengalami kesulitan untuk membuktikan unsur ada tidaknya kesalahan atau kelalaian pelaku usaha. Untuk itulah dianut doktrin productliability, dimana tergugat dianggap telah bermasalah kecuali nasabah mampu membuktikan bahwa nasabah tidak melakukan kelalaian atau kesalahan. Maka nasabah harus memikul resiko kerugian yang dialami pihak lain karena mengkonsumsi atau menggunakan produknya.

Menurut Asisten Manager Operasional PT.Bank Rakyat Indonesia, Tbk Kantor Cabang Medan Gatot Subroto. Saudara Dedi Tripiono berbicara tentang tanggungjawab bank terhadap nasabah yang dirugikan, pihak bank sangat bertanggungjawab atas kejadian yang dialami nasabah yang dirugikan tersebut. Pihak bank mengganti rugi apabila nasabah tersebut membuat surat pengaduan tentang kejadian yang dialami dan tidak merupakan kelalaian nasabah itu sendiri serta melengkapi dokumen yang dilampirkan.

\section{B. Hak dan Kewajiban Nasabah Serta Perlindungan Hukumnya}

\section{Hak Nasabah.}

Kepentingan konsumen, termasuk pula dalam hal ini nasabah, secara rinci termuat dalam Revolusi PBB Nomor 39/248 Tahun 1985. Pada sidang umum PBB ke-106 yang digelar tanggal 9 April 1985 itu, digariskan bahwa hak-hak konsumen yang dimaksud yaitu :

1. Perlindungan terhadap konsumen dari bahaya-bahaya terhadap kesehatan dan keamanannya.

2. Promosi dan perlindungan dari kepentingan sosial ekonomi konsumen.

3. Tersedianya informasi yang memadai bagi konsumen untuk memberikan mereka kemampuan melakukan pilihan yang tepat sesuai dengan kehendak dan kebutuhan pribadi. 
4. Pendidikan konsumen.

5. Tersedianya upaya ganti rugi yang efektif.

6. Kebebasan untuk membentuk organisasi konsumen dan memberikannya kesempatan kepada mereka untuk menyatakan pendapat sejak saat proses pengambilan keputusan yang berhubungan dengan kepentingan konsumen.

Pasal 4 Bab III UndangUndang Nomor 8 Tahun 1999 tentang Perlindungan Konsumen, menyebutkan hak-hak konsumen secara khusus, yaitu antara lain :

1. hak atas kenyamanan, keamanan, dan keselamatan dalam mengkonsumsi barang dan/atau jasa;

2. hak untuk memilih barang dan/atau jasa serta mendapatkan barang dan/atau jasa tersebut sesuai dengan nilai tukar dan kondisi serta jaminan yang dijanjikan;

3. hak atas informasi yang benar, jelas, dan jujur mengenai kondisi dan jaminan barang dan/atau jasa;

4. hak untuk didengar pendapat dan keluhannya atas barang dan/atau jasa yang digunakan;

5. hak untuk mendapatkan advokasi, perlindungan, dan upaya penyelesaian sengketa perlindungan konsumen secara patut.

6. hak untuk mendapat pembinaan dan pendidikan konsumen.

7. hak untuk diperlakukan atau dilayani secara benar dan jujur serta tidak diskriminatif;

8. hak untuk mendapatkan kompensasi, ganti rugi dan/atau penggantian, apabila barang dan/atau jasa yang diterima tidak sesuai dengan perjanjian atau tidak sebagaimana mestinya.

9. hak-hak yang diatur dalam ketentuan peraturan perundang-undangan lain.

Secara spesifik, hak-hak konsumen, terutama kepentingan hukumnya, telah termuat dalam Undang-Undang Nomor 8 Tahun 1999, dalam hal itu merupakan kepentingan yang mutlak dan sah bagi masyarakat Indonesia sebagai konsumen.

Hal yang tidak adil bagi konsumen bila kepentingan konsumen tidak seimbang dan tidak dihargai sebagaimana penghargaan terhadap kalangan pengusaha. Nasabah memiliki hak secara spesifik, yakni sebagai berikut :

1. Nasabah berhak untuk mengetahui secara terperinci tentang produk-produk perbankan yang ditawarkan. Hak ini merupakan hak utama dari nasabah, karena tanpa penjelasan terperinci dari bank melalui customer service nya, maka sangat sulit nasabah untuk memilih produk perbankan apa yang sesuai dengan kehendaknya. Hak-hak apa saja yang akan diterima oleh nasabah apabila nasabah mau menyerahkan dananya kepada bank untuk dikelola.

2. Nasabah berhak untuk mendapatkan bunga atas produk tabungan dan deposito yang telah diperjanjikan terlebih dahulu. Praktik perbankan berlaku ketentuan 
bahwa nasabah yang akan menyimpan dananya pada waktu suatu bank dilakukan bukan dengan cuma-cuma. Nasabah berhak untuk menerima bunga atas dana yang disimpan pada bank tersebut. Besarnya bunga ini dapat dilihat pada ketentuan yang berlaku pada setiap bank menurut produk perbankan yang ada. Bagi bank berdasarkan prinsip syariah nasabah penyimpan dana berhak atas bagian keuntungan dana yang disimpan.

Nasabah yang dirugikan atas kelalaian pihak bank akan mendapatkan pelayanan dan ditindak lanjuti apa permasalahnya, nasabah akan dikonfirmasi apabila permasalahannya sudah ditindaklanjuti, dan perbankan bertanggung jawab atas kerugian yang dialami nasabah tersebut, nasabah akan mendapatkan ganti rugi sebesar seberapa banyak hilang atas kebobolan dana di rekening nasabah tersebut.

\section{Kewajiban Nasabah}

Kewajiban nasabah, diatur dalam pasal 5 Undang-Undang Nomor 8 Tahun 1999, yang menyatakan bahwa kewajiban konsumen, yaitu :

1. Membaca atau mengikuti petunjuk informasi dan prosedur pemakaian atau pemanfaatan barang dan/atau jasa, demi keamanan dan keselamatan.

2. Beritikad baik dalam melakukan transaksi pembelian barang dan/atau jasa.

3. Membayar sesuai dengan nilai tukar yang disepakati.

4 Mengikuti upaya penyelesaian hukum sengketa perlindungan konsumen secara patuh.

Kewajiban nasabah dalam hubungannya dengan bank, pada umumnya harus memerhatikan wujud bank tersebut dengan mewakilkan pemantauan dan analisis terhadap indikatorindikator penting yang bisa mendeteksi gejala dari kemungkinan timbulnya masalah pada bank tersebut. Hal-hal yang harus diperhatikan oleh seorang nasabah dalam hubungannya dengan sebuah bank adalah menilai kewajaran terhadap tingkat suku bunga produk tabungan dan deposito, dikaitkan dengan tingkat suku bunga pasar yang umumnya berlaku. Apabila tingkat suku bunga tinggi produk tabungan dan deposito terlalu tinggi bila dibandingkan dengan tingkat suku bunga pasar pada umumnya, maka semakin besar resiko yang harus dipikul oleh seorang nasabah.

Nasabah sangat menyayangkan pihak bank, lambatnya merespon keluhan nasabah, padahal nasabah sudah melakukan pengaduan beserta melengkapi dokumen-dokumen yang dilampirkan di surat pengaduan. Akan tetapi, nasabah begitu puas terhadap pelayanan pihak bank, selama dalam pemprosesan nasabah selalu dibertahu perkembangan dan pihak bank selalu meminta maaf atas ketidaknyamanan atas kejadian tersebut. Setelah diproses selama dua (2) minggu, nasabah mendapatkan kabar, bahawasanya 
pihak bank bertanggung jawab dan melakukan ganti rugi sebesar yang telah hilang dana nya di rekening tersebut.

$$
\text { Peningkatan }
$$

dan pemberdayaan nasabah adalah dengan keberadaan insfratuktur di bank untuk menangani dan menyelesaikan berbagai keluhan dan pengaduan nasabah. Bank harus merespons cepat setiap keluhan dan pengaduan nasabah. Untuk menghindari berlarutlarutnya penanganan pengaduan nasabah diperlukan waktu yang jelas dan berlaku secara umum disetiap bank dalam menyelesaikan setiap pengaduan nasabah.

\section{III.KESIMPULAN}

Pertanggungjawaban Bank terhadap nasabah yang dirugikan sudah dilaksanakan sesuai dengan prosedur yang ada sebagaimana permasalahan perlindungan hukum dari bank, karena bentuk pertanggung jawaban bank tidak terlepas dari undang- undang yang mengikat. Arsitektur perbankan Indonesia yang di terbitkan Bank Indonesia tahun 2004, antara lain mengatur tentang perlindungan terhadap nasabah berdasarkan UndangUndang Nomor 8 Tahun 1999 tentang perlindungan konsumen. Bank menangani dan menyelesaikan keluhan dan pengaduan nasabah, dengan cara mediasi tanpa melibatkan pihak manapun dan bersedia mengganti kerugian yang dialami nasabah tersebut. Pengaduan nasabah dilakukan dengan standar waktu yang ditentukan dan berlaku secara umum.

\section{DAFTAR PUSTAKA}

1. BUKU

Bambang Sunggono, Metode Penelitian

Hukum,

Rajagrafindo

Jakarta, 1997.

Djoni S. Gazali dan Rachmadi Usman, Hukum Perbankan, Sinar Grafika, Jakarta, 2010.

Lukman Santoso Az, Hak dan Kewajiban Hukum Nasabah Bank, Pustaka Yustisia, 2011.

Ridwan H.R., Hukum Administrasi Negara, Raja Grafindo Persada, Jakarta, 2006.

Sentosa Sembiring, Hukum Perbankan, CV Mandar Maju, Bandung, 2008.

Soerjono Soekanto, Sri Mamuji Ppenelitian Hukum Normatif : Suatu Tinjauan Singkat, Raja Grafindo Persada, Jakarta, 1994.

Zainal Asikin, Pengantar Hukum

Perbankan Indonesia, Jakarta. PT Raja Grafindo Persada 2013.

\section{JURNAL DAN MAKALAH}

Ading Suryana, Upaya

Pemerintah Dalam

Meningkatkan Perhatian

Terhadap

Kepentingan Konsumen

Produk Pangan, Makalah

pada Seminar Nasional

Upaya Peningkatan

Perlinungan Konsumen

Produk Pangan, UGM,

Yogyakarta. 
Margareta Waworuntu, Tri Oldy Rotinsulu, Dennij Mandeij, PeranSektor Perbankan Dalam

MengembangkanDaya

Saing Usaha Mikro Kecil

Dan Menengah (UMKM) Indonesia Memasuki Pasar MEA 2010-2015, Jurnal Berkala Ilmiah Efisiensi Volume 17 No 01, 2017, Manado, Fakultas Ekonomi dan Bisnis Universitas Sam Ratulangi.

Rebekka Dosma Sinaga, Sistem Koordinasi Antara Bank Indonesia dan Otoritas Jasa Keuangan Dalam Pengawasan Bank Setelah Lahirnya Undang-Undang Nomor 21 Tahun 2011 Tentang Otoritas Jasa Keuangan, 2017, MedanJurnal Hukum Ekonomi Universitas Sumatera Utara.

Reza Aditya Pamuji, Perlindungan Hukum Bagi Nasabah dan Tanggung Jawab Bank Dalam Kasus Card Skimming, Jurnal Lex Rennassance Vol 3 No 1, 2018, Yogyakarta, Universitas Islam Indonesia. Wafiya, Perlindungan Hukum Bagi Nasabah Yang

Mengalami Kerugian

Dalam Transaksi

Perbankan Melalui

Internetg, Jurnal Ilmu

Hukum Kanun No 56 Th. XIV, 2012, Banda Aceh, Fakultas Hukuk Universitas Syiah Kuala.

Satria Perdana Devanto, Perlindungan Nasabah

\author{
Dalam Transaksi Melalui \\ Internet Banking, Jurnal \\ Privat Law Vol 6 No 1, \\ 2018, Solo, Universitas \\ Negeri Sebelas Maret.
}

